\title{
Association of increased extracellular volume expansion with elevated left ventricular end diastolic pressure in patients with nonischemic cardiomyopathy
}

\author{
Jie J Cao ${ }^{1,2^{*}}$, Lynette J Duncanson ${ }^{1}$, Michael Passick${ }^{1}$, Joshua Y Cheng ${ }^{1}$, Kathy Halloran ${ }^{1}$ \\ From 17th Annual SCMR Scientific Sessions \\ New Orleans, LA, USA. 16-19 January 2014
}

\section{Background}

Myocardial extracellular volume expansion is a marker of myocardial fibrosis which is associated with myocardial stiffness and impaired relaxation property. In this study we investigated the association of extracellular volume indices using T1 mapping and left ventricular end diastolic pressure (LVEDP) using left atrial transit time in patients with nonischemic cardiomyopathy.

\section{Methods}

All subjects were prospectively recruited to undergo cardiac MRI in a $1.5 \mathrm{~T}$ scanner. Modified Look-Locker Inversion recovery sequence was used with motion correction included in the post processing algorithm. Pre-contrast and post contrast (20 minutes after gadolinium injection at $0.15 \mathrm{mmol} / \mathrm{kg}$ ) T1 maps of the blood pool and myocardium were assessed in basal, mid and apical segments of the short axis planes using Siemens software. Calculated $\mathrm{T} 1$ indices were the average value of the basal and mid slice which included the pre- and post-contrast myocardial $\mathrm{T} 1$, contrast partition coefficient using the ratio of signal change in blood and myocardium before and after contrast administration, and extracellular volume fraction (ECV) which was partition coefficient multiplied with one minus hematocrit to account for the blood contrast volume of distribution. LVEDP was assessed using normalized mean left atrial transit time derived from the time-signal intensity curve of the first pass perfusion image during gadolinium injection at $0.01 \mathrm{mmol} / \mathrm{kg}$.

'St Francis Hospital, Roslyn, New York, USA

Full list of author information is available at the end of the article

\section{Results}

Compared to the normal controls $(\mathrm{N}=8)$ patients with nonischemic cardiomyopathy $(\mathrm{N}=31)$ had lower LV ejection fraction (EF) $(47 \pm 12 \%$ vs $54 \pm 3 \%, \mathrm{p}=0.021)$ and higher LVEDP $(14 \pm 5 \mathrm{mmHg}$ vs $10 \pm 2 \mathrm{mmHg}$, $\mathrm{p}=0.014)$. Using Pearson's correlation increased partition coefficient, ECV and pre-contrast myocardial T1 were significantly correlated with elevated LVEDP: $r=$ $0.385(\mathrm{p}=0.021), \mathrm{r}=0.355(\mathrm{p}=0.029)$ and $\mathrm{r}=0.335(\mathrm{p}=$ 0.04 ), respectively. In dichotomized analysis elevated LVEDP $(\geq 13 \mathrm{mmHg}, \mathrm{N}=13)$ was associated with significantly higher partition coefficient $(0.51 \pm 0.1$ vs $0.45 \pm$ $0.06, p=0.004)$, higher ECV $(0.30 \pm 0.06$ vs $0.26 \pm 0.03$, $\mathrm{p}=0.002)$ and higher pre-contrast myocardial T1 (1040 \pm $123 \mathrm{~ms}$ vs $983 \pm 44 \mathrm{~ms}, \mathrm{p}=0.045)$ when compared to those with normal LVEDP ( $<13 \mathrm{mmHg}, \mathrm{N}=26$ ). Among patients with elevated LVEDP (average $19 \pm 3 \mathrm{mmHg}$ ) there were no significant differences in partition coefficient, ECV and pre-contrast myocardial T1 between those with preserved or reduced LVEF. In contrast, there was a lack of significant association between post-contrast myocardial T1 and LVEDP.

\section{Conclusions}

Increased contrast partition coefficient, ECV and precontrast myocardial $\mathrm{T} 1$ were significantly associated with elevated LVEDP in patients with nonischemic cardiomyopathy thereby supporting the link between extracellular volume expansion and myocardial diastolic dysfunction. Quantitative tissue characterization combined with hemodynamic assessment underscores the value of cardiac MRI in the evaluation of nonischemic cardiomyopathy. 


\section{Funding}

St Francis Research Fundation.

\section{Authors' details}

${ }^{1}$ St Francis Hospital, Roslyn, New York, USA. ${ }^{2}$ Cardiology, State University of New York at Stony Brook, Stony Brook, New York, USA.

Published: 16 January 2014

doi:10.1186/1532-429X-16-S1-P316

Cite this article as: Cao et al:: Association of increased extracellular volume expansion with elevated left ventricular end diastolic pressure in patients with nonischemic cardiomyopathy. Journal of Cardiovascular Magnetic Resonance 2014 16(Suppl 1):P316.

Submit your next manuscript to BioMed Central and take full advantage of:

- Convenient online submission

- Thorough peer review

- No space constraints or color figure charges

- Immediate publication on acceptance

- Inclusion in PubMed, CAS, Scopus and Google Scholar

- Research which is freely available for redistribution

Submit your manuscript at www.biomedcentral.com/submit
C Biomed Central 